\title{
A Sketch of the geology of Jamaica
}

\section{After E. T. Hill}

To cite this article: After E. T. Hill (1899) A Sketch of the geology of Jamaica, Scottish Geographical Magazine, 15:12, 628-639, DOI: 10.1080/00369229908733108

To link to this article: http://dx.doi.org/10.1080/00369229908733108

曲 Published online: 27 Feb 2008.

Submit your article to this journal $2 \pi$

山 Article views: 13

Q View related articles $\asymp$ 


\title{
A SKETCH OF THE GEOLOGY OF JAMAICA. ${ }^{1}$
}

\author{
After R. T. HILL of the U.S. Geological Survey.
}

The relief of Jamaica is distinctly mountainous, and at the first distant view from the east the island presents a group of mountain summits rising above the sea in a tangled mass, without systematic ridges or secondary types of relief. But on a nearer approach four distinct predominant types are easily recognisable, besides numerous secondary modifications. The chief features are (1) the interior mountain ranges constituting the nucleus of the island; (2) an elevated limestone plateau, which surrounds the interior mountains and ends abruptly towards the sea; (3) the coastal bluffs or back coast border of the seaward margin of the plateau; and (4) a series of low, flat coastal plains around the periphery of the island, between the sea and the back coast border. The relation of the plateau region to the interior mountains is that of an elongated bench completely surrounding a higher sierra, the plateau having an outline somewhat like a child's bib, the mountains of the east protruding through the neck, while the main expanse, stretching westwards, presents occasional views of the buried mountain structure through rents and holes made by water. The interior mountains are marked by deeply etched salients and re-entering angles, whereas the hills of the limestone plateau present uncorrugated, densely wooded slope?

The mountains of the interior comprise the Blue Mountain ridge, which dominates the topography of the eastern third of the island, and certain isolated summits to the west of the Blue Mountains proper, such as Jerusalem mountain in Westmoreland, and the Clarendon mountains. The isolated groups occur as limited inliers, surrounded and overlooked by hills of the limestone plateau. The Blue Mountains extend in a sinuous axis with many branches along a third of the length of the island, from near the eastern point, and trend to the north of west, parallel to the truncated north-east coast. The serrated crest culminates near the centre of the ridge in Blue Mountain Peak, 7360 feet high. West of this peak the elevation decreases till, at last, it sinks below that of the limestone hills beneath which the mountain structure was buried in ancient times. Westward of St. Catherine Peak (5036 feet), almost due north-east of Kingston, the main range bifurcates. The southern and larger branch continues in a sinuous course towards the north-west through St. Andrew, where it is known as the Ram's Horn ridge and Above Rocks, and on between St. Andrew and St. Mary as Goddard ridge to the drainage divide of the Rio Doro and Trumbell's river, near the line of the Port Antonio railway. Several other ridges radiate out from Catherine Peak to the north-west. All the western branches of the Blue Mountains terminate on the eastern side of the great basin of St. Thomas-in-the-Vale.

1 Extracted from "The Geology and Physical Geography of Jamaica," by Robert T. Hill. Bulletin of the Museum of Comparative Zoology, Harvard College, vol, xxxiv. 
The mountains are composed of friable or loosely consolidated shales, clays, and conglomerates, with here and there a local bed of limestone or an occasional dyke of igneous rock, and their present configuration is due to the readiness with which they yield to erosion. The Blue Mountains are the highest of an extensive system of corrugations which were partially buried, especially to the west of the centre of the island, during a period of subsidence, under a mantle of white limestone, and has since been re-elevated to a height of 3000 feet. The old structure and material reappear in many places in the great central valleys of St. Thomas-in-the Vale, Clarendon parish, etc., where the limestone has been worn away, and are also visible below the limestone in the face of the back coast bluffs along the western half of the north side of the island.

The geographic centre of Jamaica is marked by a most interesting , topographic feature, an anticlinal valley worn out of the crest of the low arch of the white limestone plateau. An elongated oval, fifty miles in length, mostly in Clarendon parish, this great amphitheatre is surrounded on all sides by the inward-facing breaks of the limestone, which rise 2558 feet on the south and 3000 feet on the west side. Most of the area of the valley is occupied by two parallel ridges, with laterals and outliers. The northern, dividing the Minho from the St. Thomas river, is known as the Main ridge; the other, parting the basin of the Minho from the Cave and Pindar rivers, which may be called the Santa Maria ridge, culminates in Bull Head. These ridges consist of the same material as the Blue Mountains, trend also northwards, but are not so serrated. The heights of these mountains (Bull Head, 2885 feet, and the Main ridge, 2542 feet) nowhere exceed that of the limestone plateau. They are modern drainage divides, and were at one time completely covered by the limestone. In the south-east corner of Hanover parish, in the valley of Great river, and at Jerusalem mountain, in the north central portion of Westmoreland, the central mountain rocks are also exposed by denudation.

This structure is intensely folded. In the east it is a crumpled anticline, and has been subjected to additional disturbance by the intrusion of a great mass of granitoid porphyry, with many auxiliary dykes, which is now exposed on the north side of the west end of the ridges in St. Mary. In general all the central mountain structure occurs along three lines of strike, probably representing the outcrop of two original lines of corrugation, the ends of which overlap en échelon. The Blue Mountain ridge is the most northern and eastern of these old corrugations, the Clarendon and Hanover exposures an intermediate one, and the Jerusalem the most southern and western. As this structure is found in the bluffs on the north coast, it may be concluded that at one time it formed a mountainous region, covering a larger area than the whole of the present island.

The plateau region is now a much dissected plain, rising to a height of 3000 feet. Its greatest extension is to the west of the Blue Mountains, where it stretches all across the island, and, in all, it occupies fully fourfifths of the total area. Its profile, were the irregularities caused by erosion filled up, would be a gentle arch sloping north and south towards the sea, and meeting it far beyond the present margin of the land. The 
edge of this plateau is in many places marked by benches and terraces constituting the back coast border. The highest summits of the plateau are found in the crests surrounding the Clarendon basin, which attain a maximum altitude of about 3000 feet, or less than one-half that of the Blue Mountain peaks. The John Crow ridge on the east (2100 feet) may be either a remnant of the old summit-level or the oldest and highest of the base-level plains cut out of its marginal topography. On the south side of the Blue Mountain ridge, the highest summit of the Yallahs mountain (2254 feet) is the only remnant of the old topography on that side of the island. Isolated remnants of the plateau, separated by the indentations of the lower-lying coastal plains, occur at Port Henderson, the Healthshire hills of St. Catherine, the Braziletto mountains, and the Portland hills of Clarendon.

The materials of the platean are soluble limestones-old sheets of calcareous oceanic sediments now chalky or subcrystalline in texture. The hills, especially in the interior, owe their configuration largely to solution, while the forms of the central mountains are due to denudation. The summit of the plateau is a roughly serrated, hilly country indented by cockpits (sink holes), sub-circular basin valleys, and deep drainageways leading to the sea. The origin of this topography can be best illustrated by a description of the Cockpit Country, as it is locally called. It extends over all the higher ground to the north and west of the Clarendon ridges, though the actual cockpits are confined to the corners of the parishes of Trelawney and St. James. In the interior of the western half of the island the hills are sharply rounded conical points; towards. the coast are flat-topped ridges such as the John Crow ridge, the Yallahs ridge, and many others; while table-topped elevations with steep flanks occur in parts of Westmoreland and Hanover. The cockpits vary in depth from shallow, circular basin-like depressions surrounded by low mamillary hills to deep-side sinks often 500 feet deep. These are developed in the upper part of the white limestone. Below is another white limestone, also soluble but less pervious than the former, and, below this again, nodular limestones, clays, and conglomerates of the older insoluble and impervious formation which checks the downward course of the lime-charged waters and forces them to take a horizontal direction.

When the bottoms of the cockpits reach the more resisting limestones of the second group, their perimeters begin to expand, and round or oval valleys with steep sides are formed, known in Jamaica as lightholes. As the downward process continues the lower limestone is dissected into flat-topped remnants and finally removed altogether. At the level of the older mountain material solution ceases, and the valleys expand by erosion into extensive circular enclosed basins. Furthermore, great springs of water break out at the contact of the limestones and clays, and by their erosion help to carve out the floor of these basins into miniature mountain forms, thus reviving the antecedent topography. Ultimately the barriers between the basins and the coastal drainage areas are broken through.

The many basin-shaped depressions in the plateau region constitute 
some of the most interesting physiographic features of the island. They differ from one another chiefly in area and the irregularities of the relief of the bottoms, which seldom lie more than 400 feet above sea-level, while the surrounding hills rise 1200 to 2500 feet above them. 'The largest of these depressions are those of St. Thomas-in-the-Vale, the great vale of Clarendon, the Hector river basin in northern Manchester, and the Niagara valley along the boundary of St. Elizabeth and St. James. The valley of St. Thomas is almost circular in outline, and its floor has a diameter of ten miles. Its bottom is largely covered with old alluvium. On the west side of the valley a band of white limestone rising in a gentle arch extends for miles towards Moneague and culminates in Mount Diablo, 2500 feet above the bottom of the basin. The valley is drained by ten copious streams, the feeders of the Rio Cobre, which through the Bog Walk cañon finds its way to the sea. The Clarendon valley is 50 long by 25 broad, and is drained by the affluents of the Minho. On the north-west is the Hector river basin, separated by a low saddle. At present it has no direct outlet to the sea, but its drainage sinks into the limestones on the east. Cave valley is in a similar condition. These are only a few of such valleys lying along the central axis of the plateau. There are several others, besides smaller and less important sinks, in the western portion of the island. They are all connected phenomena and illustrate the powerful effect of solution and erosion in producing the hilly topography of the white limestone districts of Jamaica and the Tropics in general. Should the island undergo no more uplift, solution alone would entirely remove in time the white limestones now veneering the older insoluble Blue Mountain rocks. The margins of the platean have been similarly affected.

The seaward margin has been planed away horizontally, as is shown by a study of the back coast topography, which presents a steeply sloping, mountainous front rising to an average altitude of 1200 feet along the north coast. It presents a most interesting series of ancient terrace levels, most beautifully shown on the east side of Montego bay, where six distinct benches separated by steep slopes rise in stairs above the sea. Though not as perfect as in Cuba, the Jamaica terraces record a similar geological history. The highest of the old benches is John Crow ridge, apparently a continuous horizontal platean ending to the south-east in Big Level. On the west it is separated from the Blue Mountains by the tremendous ravine of the Rio Grande. The higher summit of Yallahs mountain, Dolphin Head (1800 feet), and other points in Hanover, may be remnants of the John Crow level. The next persistent level corresponds to an altitude of 1500 feet. It is noticeable as the long horizontal sky-line of many of the so-called mountains of which Long mountain, east of Kingston, is a type, and is largely developed on the south coast of the island, but does not appear on the north coast. The third conspicuous bench has an altitude closely approximating 1000 feet. This is the level of a great dissected plain extending along the northern side of the island west of Port Antonio and known as the North Coast ranges, and it is also well marked on the south coast. These benches at the 2100,1500 , and 1000 foot levels are connected 
phenomena, and represent a distinct stage of elevation in Antillean history.

A lower group of levels occurs at altitudes of 650,300 , and 200 feet, becoming more distinct and persistent with decreasing altitude. The back coast benches have all been cut out of the land by base levelling and marine erosion, those between 700 and 2000 feet out of the white limestone during the first period of emergence from the sea, and those from 100 to 700 feet out of the old limestone matrix during a second period of emergence following on a subsidence. There is abundant evidence that old gradational terraces continue lower down upon the submerged slope of the island, and that the phenomena of the coastal plain represent veneerings of organic, littoral, and terrigenous deposits upon old erosion plains of this character.

A narrow strip of low land extends almost uninterruptedly around the island between the sea and the back coast border. This strip is composite in character, being of three types of formations, such as elevated reefs, marginal sea débris, and land alluvium. It includes benches of different height and origin, and a long and gentle slope known as the Liguanea plain. The highest of the benches, composed of sea sediments, are from 100 to 150 feet. The elevated reefs are three in number, approximating 15,25 , and 60 feet above the sea respectively. The coastal plains and slopes, covered with alluvium, are of a peculiar type, and represent old plains of erosion. They comprise extensive areas indenting the back coast topography, especially on the south side of the island. Chief among them is the Liguanea plain on which Kingston stands. It is over 25 miles long by 6 miles wide on an average, and has an area of about 200 square miles. The interior margin is over 800 feet high near Constant Springs, whence it slopes rapidly to the sea at Kingston, $6 \frac{1}{2}$ miles distant. The aspect of this plain is comparatively bare and sterile, its flora, including thorny cactus and acacia, presenting a striking contrast to the deciduous tropical flora of the remainder of the island. The history of the plains of the Liguanea type is a record of four distinct events:-(1) The original cutting out of the topographic matrix during a period of base levelling; (2) the filling in of the material constituting the present surface; (3) the elevation of the plains into their present position above the sea; and (4) the cutting of the modern streamways across them.

As a whole the island presents two major types of streams, one of simple autogenous rivers flowing to either coast, and the other the streams of the interior basins which have no outlet to the sea; a third and more complicated type of drainage has been produced in certain instances by the capture of the second by the first type. The rivers of the eastern third of the island flow from the Blue Mountains to the sea, in general normal to the coast. They have deep V-shaped cañons in their upper courses and great deposits of alluvium in their lower parts. In the valleys of the Liguanea type the bights occupied by the plains were once headwater amphitheatres from which the streams flowed over a wider coastal border than at present. This border was subsequently submerged, so that the original headwaters became estuaries, and finally 
elevation partly reclaimed the coastal plain. The drainage of the limestone plateau is both superficial and underground. To the former system belong the older and longer streams which brought down the material now forming the coastal plain, and shorter streams, probably of later origin, which flow from the cliffs of the back coast border. The streams of the limestone plateau summit region are of a different type. Many of the streams rise from springs near the contact of the white limestone and Blue Mountain series, and after short courses disappear into the ground without any visible outlet to the sea. In many cases the headwaters of the marginal streams have captured the drainage of the interior valleys, especially the Minho, Cobre, Montego, Black river, and Great river.

The geologic formations of Jamaica belong to four great categories:-

(1) A fundamental series of stratified shales and conglomerates, tuffs and other débris of volcanic material, and, rarely, marine limestones and marls, all of which have undergone great displacements and deformation. These compose the higher mountains and the nucleus of the island structure.

(2) A series of originally derived oceanic material-marls and limestones-which rests unconformably upon, but does not completely overlap, the more elevated outcrops of the first-mentioned series.

(3) Laccoliths, dykes and sills of igneous rocks, which penetrate the first series and the lower portion of the second, and are, therefore, of later age than both.

(4) Certain deposits of alluvium, oceanic marls, and coral reef rock, which are adjacent to the present coasts and represent fringing reefs and other accretions around the island's border after it had almost attained its present area and outline.

All these series Mr. Hill describes at considerable length; here it is possible only to report a few of his general conclusions.

Of the first, or Blue Mountain, series he gives a more accurate classifcation than has hitherto been made, dividing it into an upper division (Eocene) represented by the Richmond beds, and a lower division (Upper Cretaceous), comprising in descending order the Minho, Ballard, Logie Green, Frankenfield, Jerusalem, and Yallahs beds. The complex folding and partial concealment render it impossible to determine the exact base of the series. The Jamaican Reports state in different places that the base of the section is composed of igneous rocks, Cretaceous limestones, and a formation termed the "Metamorphosed Series." Sawkins expresses a doubt as to the propriety of drawing a distinction between the Cretaceous and "Metamorphosed Series," the latter including strata which have merely experienced a change of structure owing to the intrusion of igneous rocks. Mr. Hill also concludes from his own observations that the "Metamorphosed Series," as a structural formation, may be dismissed from consideration. The fossiliferous Cretaceous beds seem to be local occurrences in the great and tangled series of tuffs and conglomerates, the latter of which constitute the visible base of the section. Evidence of some older or lower-lying rocks beneath the Blue Mountain series, such as are reported in Cuba and Haiti, were sought for in vain.

voL. XV. 
In nearly all the localities of the Jamaican survey the limestones have the appearance of localised beds in the midst of the general material of the Blue Mountain series, and probably, as Sawkins suggested, originally formed isolated reefs. To the bedded limestones succeed the marls, varying from fifty feet to an inch in thickness. In general these clays contain fossils which represent intermittent life colonies, which existed in periods of quiescence during the irregular deposition of the earlier part of the Blue Mountain series. Sawkins has spoken of the limestones as "forming a zone around the great nucleus of upheaval of the island." If this were so, much of the Blue Mountain series might be antecedent to these beds. But these limestones not only lie round, but are folded in, the plexus of beds constituting the highest mountains, occurring on Blue Mountain Peak as high as Abbey Green, 4200 feet above the sea.

The tuffs, igneous pebbles and boulders of the lower subdivision are composed almost entirely of hornblendic material-andesites and porphyries-which shows that this .was the chief eruptive material of Jamaica during this epoch, and of which the Minho beds apparently represent the débris of the last expiring extrusion. All the beds of the subdivision are the product of active vulcanism, accompanied by the piling up and contemporaneous degradation of vast quantities of igneous material, and of short intermediate periods of quiescence when shales and marls were permitted to accumulate and sparse faunas to gain temporary foothold.

The Richmond beds are mostly black bituminous laminated clays and ferruginous sandstones, with occasional beds of loose conglomerate. The material is mostly derived from the antecedent beds of the lower division of the Blue Mountain series. The conglomerates consist of rounded pebbles of various dimensions, and in places attain a thickness of 50 feet. They are almost entirely of the same material as the lower division, but specimens of gneiss and crystalline slates have been found in them, as well as of a fine-grained granite-rocks hitherto unknown in Jamaica. The ordinary sandstone in its extension seawards becomes a promiscuous assemblage of large pebbles, six or eight inches in diameter, which indicates that some of this material came from the area to the north, now occupied by the sea.

The interpretation of the white limestones has been one of the greatest problems of Jamaican geology. They have generally been discussed by field observers under one head, but the truth is that they represent several distinct formations and ages, from Vicksburg to recent, inclusive, but that the greater portion are of old Oligocene age. The older white limestones are of the Vicksburg stage, which is placed in the Eocene by some writers, and in the Oligocene by others; the later are of Pliocene, Pleistocene, and recent age. Some writers have believed that all the white limestones are of coral reef origin, and hence have carelessly asserted that reef rocks occur in the Antilles at heights exceeding 2000 feet, whereas, except in Barbados, such rocks nowhere exceed 100 feet in altitude and thickness. In fact, the larger thicknesses of these limestones, as shown by their microscopic fossils, are neither of molluscan, coralline, nor reef rock origin, but are foraminiferal oceanic 
deposits and other offshore calcareous oceanic muds composed of organic detritus laid down at depths below that at which reef rocks were formed, and in periods of geological time prior to the appearance of the modern reef-building species in the sequence. This Oceanic series, as it may be called, consists of white limestones probably aggregating 2000 feet in thickness, and occupies most of the plateau, which includes all the island under 3000 feet in altitude outside the Blue Mountain district, except the immediate coastal border.

The coastal series includes a class of formations which represent the products of events more recent in the history of the Jamaican series than those hitherto enumerated. The beds lie principally along the margin of the sea at altitudes nowhere exceeding 250 feet, the Bowden beds being the uppermost, and are deposited unconformably against the sides of an older mainland. They were all made during epochs subsequent to an epoch of elevation, whereby the white limestones of the Oceanic series, and all preceding formations, had been elevated into land, had undergone tremendous denudation, and had again suffered partial marginal subsidence. They are of four types-beds of impure marine limestone; gravel and marl; alluvium of the Kingston type; elevated coral reefs; and littoral deposits of calcareous mud, with fossils of contemporaneous origin with the elevated reef formation. In general they are analogous in their lithological character to the formations now being made around the margins of Jamaica.

The old reefs grew upon marginal terraces which, previous to their submergence, were probably wave-cut, constructional, or gradational plains, like those now seen upon the land configuration. As they successively rose to within twenty fathoms or less of the surface, the zone of coral growth, they were occupied by the polyps which constructed the reef which has since been elevated into dry land. Similar submerged plains are now occupied by growing reefs around the island. In general the old reef rock of Jamaica consists of three distinct formations, occurring at levels of 70,25 , and 10 feet (or less) respectively. The present land margin is not continuously fringed by growing reefs, but these occur in interrupted patches, alternating here and there with strips of different kinds of bottom, such as alluvial deposits opposite the mouths of rivers, shell, sand, or lagoon mud; and similar conditions prevailed during the growth of the old reefs.

It has been said above that the oldest known rocks of the island are undoubtedly rolled eruptive volcanic débris, and that no fundamental masses of plutonic crystalline rocks, granite or others, are known to occur as a previously formed basement to the sedimentary section of Jamaica. These rocks, however, are all eruptive and intrusive and in age are contemporaneous with the sedimentary rocks. The igneous rocks may be classified into three distinct categories:-(1) The andesitic (mostly hornblende) boulders, pebbles, and tuffs of the Blue Mountain series of eruptive origin from unknown vents, contemporaneously deposited with the Cretaceous sediments of the lower beds. (2) The hornblende-diorite and granitoid porphyries of the five eastern parishes of the island, constituting dykes and masses, or laccoliths, intruded 
through the rocks of the Blue Mountain series, and into the Montpelier formation of the oceanic series. These rocks are of Mid-Tertiary age. (3) Eruptive amygdaloidal basalts of the Low Layton stock or volcanic neck in the north coast of Portland, also Mid-Tertiary.

There is some reason to believe that the eruption of the hornblendeandesites continued throughout the epoch of the deposition of the lower subdivision of the Blue Mountain series up to the time of the commencement of the Richmond formation, while the latter by its more regular stratification and composition, though it contains vast quantities of water-worn volcanic pebbles, indicates that a more stable period had set in. The second class of rocks are of deep-seated origin, and, as no evidence exists that they ever protruded to the surface, they probably represent a great laccolith, which in middle Oligocene times was forced upwards into the existing formations. It seems probable also that the intrusion of these rocks was associated with the elevation of the island and the progressive shallowing so evident in the ascending sequence of the white limestone, whereby they changed from the deep sea foraminiferal deposits of the Montpelier beds into more shallow limestones, and finally into the land areas which existed at the time of the peripheral deposition of the Bowden Oligocene.

At only one locality in the island is there supposed evidence of the occurrence of true volcanic rocks in situ, namely, at the Black Hill near Low Layton. Since the hill was examined by Brown, a tunnel for the Jamaica railway has been cut through its base; and it has been found that the igneous rocks extend down to 700 feet below the summit, and that these rocks are of the nature of a volcanic neck rather than an entirely superficial lava flow. Characteristic fossils and chalk of the Montpelier limestone in the scoriaceous cavities of the basalt indicate that the limestone was deposited contemporaneously with, or after, the basalt, and perhaps the yellow marls lying in some places almost horizontally upon it may belong to the Bowden formation of late Oligocene age. If this be so, the Low Layton rocks date from the Montpelier epoch or before, but further research is needed to settle the question. At any rate, the Low Layton "volcano" is composed of the latest igneous rocks in Jamaican history. The intrusion of these granitoid and dioritic rocks has produced extensive metamorphism of the adjacent rocks, baking the shales into hard friable slates and indurating the Cretaceous limestones.

After an examination of the palæontology of the Jamaican rocks, which yields evidence in support of his conclusions, Mr. Hill describes the evolution of the island. What part the locus of the island played in the earlier struggles between sea and land cannot be at present stated, but at all events in late Cretaceous times the crests appeared above the waters and grew more conspicuous in succeeding epochs. The nature of the oldest known rocks in Jamaica proves clearly that in late Cretaceous times volcanic eruption was active at or near the island, while the colonies of peculiar fossils imbedded at intervals in these rocks fix the time of their origin. Furthermore, the species themselves, their faunal assemblage, and the circular arrangement of the colonies round 
the nuclei of the Blue Mountain and Clarendon ridges, may possibly indicate that there were several centres of this eruption. The débris was enormous, the thickness of the still remaining portion being at least 5000 feet. These volcanic outbreaks were not confined to Jamaica.

The next event in Jamaican history was the degradation of the nucleal volcanic heaps by erosion. The thickness of the resulting sediments, aggregating 1500 feet or more, attests the existence of a high preexisting land, and the abundant plant remains show that it was covered with dense vegetation. The uniform alternations, the wide extent of the formation, and the occasional presence of marine fossils, show that the material was sorted in shallow waters. This fact, together with the presence of a few pebbles of foreign origin, the absence so far as known of any distinct estuarine deposits, and the widespread occurrence of similar formations in the West Indies, suggests the existence at that time of larger land areas in this region than the mere nucleal summits.

There is also evidence that subsidence accompanied this deposition, and that the two processes so nearly balanced that the bottom did not materially change. These events were also closely followed by folding of the strata. The older beds of the Blue Mountain series, the Cretaceous limestones and Richmond beds, are all turned up together in this complicated system of foldings, and inseparably constitute the summits of the Blue Mountain ridge, which between the altitudes of 3000 and 7325 feet now protrude 4325 feet above all the later Eocene and oligocene formations. As the overlying strata do not exhibit such intensity of disturbance, and some of the later beds seem to lie unconformably upon the Richmond, an interruption of sedimentation and a corrugation of the strata may have taken place after the Richmond deposition period, perhaps connected with the uplifts which had farreaching importance in Antillean history, and were accompanied by active vulcanism in the isthmian and probably in the Windward regions. If, on the other hand, this folding did not occur at this particular efoch, then the Richmond beds may mark the initiation of a great subsidence so clearly traceable in the succeeding epoch.

This subsidence was one of the most important and extensive in all Antillean history. Cañon cuttings through the collar of the limestone plateau round the peaks of the Blue Mountain structure show that the latter extends down to sea-level, and nearly everywhere to the present margin of the island. The limestone deposits of the subsidence encrust this mountainous core to a height of 3000 feet, and hence only the portion of the summits above that altitude could have been dry land when the subsidence was at its maximum. The culmination of this subsidence can be fixed by palæontologic evidence at the close of the Eocene period, Vicksburg epoch.

The next event in Jamaican history was the re-elevation of the sea and the restoration of the land to far beyond its present outline, connecting it with the island of Haiti, and possibly with the Central American region. The emergence of the island brought up a portion of the old mountainous topography encrusted by a coating 1000 feet or more of oceanic chalks. The low east and west fold through the 
geographic centre of the island, which dominates this emergence, produced a gentle arch inclining north and south. Accompanying the uplift was the great intrusion of the deep-seated granitoid and dioritic rocks already mentioned, if it were not its direct cause. The higher terraces, between 1000 and 2100 feet, seem to have been formed during or immediately following this emergence epoch, and previous to the next subsidence.

This subsidence led to a contraction of the land to its present back coast borders. It was initiated by the deposition of the Bowden gravels, found only on the north and south coasts of the eastern portions of the island, and probably culminated in the deposits of the shallow marls. The amplitude of the movement was probably less than one-third that of the former subsidence, for the Bowden and Cobre beds encrust the base of the island up to a height of less than 300 feet.

Then another upward movement of 500 feet and more brought up not only the present marginal border composed of the new-made sediments of the Bowden epoch, but a now slightly submerged area towards the south, which extended at least as far as the present 500-fathom line, embracing the San Pedro banks and cays. Though accompanied by slight deformation, it was less orogenic than the upheaval of the preceding epoch. Great erosion and denudation, following on this upheaval in late Miocene or early Pliocene time, produced the surface configuration of to-day, and the country adjacent to the lower portions of the island became extensive base-levelled plains, and included what are now the submerged benches of the island, which were coated with the Kingston formation during a subsequent subsidence. At that time the middle series of terraces, 200 to 700 feet high, was cut around the coastward face of the back coast country.

Possibly there was another subsidence in late Pliocene times, when the coastal plains were submerged, and deeply indented estuaries were formed at the mouths of the great rivers. Lastly came the series of elevations which have continued up to the present time, and are marked by the terraces of reef rock at altitudes of 60,25 , and 15 feet. Similar reefs continued to grow in the adjacent waters, which may in their turn be raised above the surface. As the elevated reefs are made up entirely of existing forms, their date cannot be earlier than the close of the Pleistocene age.

Mr. Hill enters at considerable length into the question of the relations of the Jamaican formations to those of adjacent regions, and into the geological history of the Antilles in general. The Jamaica sequence, so far as it reaches backward in time, is remarkably like that of the great Antilles, and may be distinctly termed the Antillean type. In Cuba and Haiti alone of the West Indian islands (Trinidad being essentially South American) is it at all probable that Pre-Cretaceous or older rocks than in Jamaica are exposed, though it is theoretically possible that the submerged portions of all may have a Palæozoic foundation.

The final conclusions regarding Antillean history are that no land connection can be inferred between these islands and the continents in Post-Jurassic times, and that their configuration and condition in PreJurassic times cannot even be surmised. There are some hypothetical 
and biologic reasons for believing that the outer rim of the American Mediterranean constituted a partial or complete bridge between the continents in Jurassic times, and that the Panama bridge did not exist. The first definite evidence of the existence of the islands is found in the eruptive rocks of late Cretaceous times, and the land débris constituting the Eocene strata testifies the pre-existence of extensive Cretaceous land areas. In late Eocene and early Oligocene times a profound subsidence submerged all but the highest tips of the Antilles, and this movement extended to the margins of the surrounding continents. In late Oligocene or Miocene times a tremendous uplift connected many of the islands without, however, entirely bridging over the interval between the North and South American continents. In Miocene or early Pliocene time the islands were again severed by submergence, and assumed their present forms, which have subsequently been affected by only secondary modifications. Since then there have been intermittent periods of elevation without serious deformation, but not sufficient to restore the islands to the heights of Mid-Tertiary time. The Pleistocene movements were not uniform in all parts of the area, showing great differences of amplitude in the West Indian region, and were not harmonious with those of the North American coastal plain. The irregularities of the submerged configuration are orogenic, and not due to submerged Continental drainage systems. The elevated coral reefs of the West Indies were formed on rising lands.

Mr. Hill's work is illustrated by numerous photographs and a contoured and a geological map of the island, from the latter of which some details have been inserted in the map accompanying this number of the Magazine. Mr. T. Wayland Vaughan contributes an appendix on some Cretaceous and Eocene corals of Jamaica.

\section{AN ANTHROPOLOGICAL STUDY OF CORSICA. ${ }^{1}$}

Corsica is the northernmost of the larger Mediterranean islands, projecting from the line of the Balearic islands, Sardinia and Sicily. From Sardinia it is separated by depths not exceeding 55 fathoms, and is connected with it by a group of islets (Cavallo, Lavezzi) in the strait of Bonifacio. Off the north and west coasts the depths are great, descending to about 1600 fathoms, while on the east, between Corsica and Leghorn, the sea is nowhere deeper than 110 fathoms, though it grows rapidly deeper to the south, up to 550 fathoms. Between Corsica and the Tuscan coast the distance is 50 miles. The community of origin between Corsica and Sardinia is shown in the identity of the direction of their longitudinal axes, which make with that of the Apennine peninsula an angle of $55^{\circ}$. Thus the Tyrrhenian sea, shut off from the Spanish part of the Mediterranean and closed at the south by Sicily, forms a kind of inland sea which has always been of more importance to these islands than the Mediterranean without. It is

1 Résumé of an article by Professor Ratzel in the Annales de Géographie, No. 40. 